\title{
Menengok Arsitektur Permukiman Masyarakat Badui : Arsitektur Berkelanjutan dari Halaman Sendiri
}

\author{
Agung Budi Sardjono ${ }^{1}$ dan Satrio Nugroho ${ }^{1}$ \\ ${ }^{1}$ Dosen Jurusan Arsitektur Fak. Teknik Universitas Diponegoro Semarang
}

\section{Kata Kunci/ Keywords :}

Arsitektur Berkelanjutan, Tradisi Bermukim, Masyarakat Badui

Sustainable architecture, Living Tradition, Bedouin community

\begin{abstract}
Abstrak:
The energy crisis and the damage to the natural environment encouraged public awareness for the preservation of nature in addition to pay more attention to the welfare of mankind. Sustainable development with architecture in it developed into an important issue in recent decades. Wisdom in the culture of the archipelago can be a role model in tackling the crisis. Badui community is a bit of a tribe that still retains its cultural traditions closely until now. The tradition of the Badui community living utmost respect and preservation of nature where they live. Using natural resources in a selective; appropriate technology; restrictions and strict rules generate a culture living in harmony with nature. A science that needs to be studied, imitated and developed to address modern challenges. This paper aims to assess the alignment of the Badui community living tradition with the characteristics of Sustainable Architecture.
\end{abstract}

Krisis energi dan kerusakan lingkungan alam mendorong kesadaran masyarakat untuk lebih memperhatikan kelestarian alam disamping kesejahteraan umat manusia. Pembangunan berkelanjutan dengan arsitektur di dalamnya berkembang menjadi isu penting dalam beberapa dasawarsa terakhir. Kearifan dalam kebudayaan Nusantara dapat menjadi teladan dalam menanggulangi krisis tersebut. Masyarakat Badui merupakan sedikit dari suku yang masih mempertahankan tradisi kebudayaannya dengan ketat sampai saat ini. Tradisi bermukim masyarakat Badui sangat hormat dan menjaga kelestarian alam tempat mereka tinggal. Pemanfaatan sumber daya alam yang selektif; teknologi tepat guna; larangan dan aturan yang ketat menghasilkan budaya bermukim yang selaras dengan alam. Sebuah ilmu yang perlu dipelajari, diteladani dan dikembangkan untuk menjawab tantangan modern. Tulisan ini bertujuan untuk mengkaji keselarasan tradisi bermukim masyarakat Badui dengan karakteristik Arsitektur Berkelanjutan.

Sitasi:

Sardjono, Agung Budi, dkk. (2017). Menengok Arsitektur Permukiman Masyarakat Badui.Arsitektur Berkelanjutan Dari Halaman Sendiri . Jurnal Teknik Sipil \& Perencanaan, 19 (1), 57 - 64

(C) 2017 Universitas Negeri Semarang

\footnotetext{
Agung Budi Sardjono:

Universitas Diponegoro

Jl. Prof. Soedarto, Tembalang, Kota Semarang

E-mail : nuci@yahoo.com
} 


\section{PENDAHULUAN}

Dalam tiga dekade terakhir krisis energi dan kerusakan lingkungan mungkin merupakan isu yang paling banya dibicarakan masyarakat dunia. Krisis tersebut mengancam kesejahteraan manusia dan juga kelestarian alam secara menyeluruh. Capra (2006:515) menengarai bermacam-macam bencana, krisis serta kerusakan tersebut saling berhubungan dan bersumber dari cara pandang yang mekanistis dan lebih berorientasi pada manusia (antropocentris) (Hadi, 2009:17). Kondisi tersebut mendorong kesadaran manusia untuk merombak cara pandang lama dengan cara pandang yang lebih holistik ekologis, bahwa manusia bukan pusat segalanya, melainkan salah satu dan demikian banyak elemen yang berhubungan dan menyusun alam semesta. Gerakan kesadaran ini tumbuh dalam bentuk Sustainable Development dan berkembang dengan bermacam macam sebutan. Bidang arsitekturpun tidak terlepas pengaruh gelombang kesadaran tadi. Bahkan arsitektur sebagai sebuah ilmu rancangan yang menghasilkan bangunan merupakan target penting bagi gerakan ini. Menurut Wines (2008:12), bangunan merupakan penghisap energi yang cukup besar di dunia. Bangunan mengkonsumsi seperenam sumber air bersih, seperempat kayu alam dan duaperlima bahan bakar fosil. Berawal dari sebutan Sustaiable Architecture sebagai gagasan konsep pembangunan berkelanjutan di bidang arsitektur kemudian berkembang sampai sekarang dikenal sebagai Green Architecture. Arsitektur hijau dapat dikatakan sebagai gerakan dalam bidang arsitektur yang mempertimbangkan konsep pembangunan berkelanjutan dalam kaidahkaidahnya (Saraswati, 2011:4).

Bermacam penelitian, pengembangan ilmu dan teknologi serta rancangan modern dikerahkan untuk mendukung gerakan kesadaran lingkungan. Indonesia sebagai bagian dari masyarakat duniapun tidak lekang dari eforia tersebut. Banyak diantara kita yang demikian kagum dengan hasil pemikiran para ahli dan pemikir Barat tentang green architecture dan mencoba menerapannya di sini. Sebagian ahli rupanya berpendapat lain, bahwa ilmu pengetahuan dan teknologi yang paling cocok diterapkan di Indosesia selayaknya digali dari bumi Indonesia sendiri. Kekayaan budaya masyarakat Nusantara menyediakan sumber yang tiada tara untuk digali, ditemukan kembali dan dikembangkan untuk menjawab tantangan pada saat ini (Pangarsa,2007:56). Salah satunya adalah masyarakat Badui di Banten.

Masyarakat Badui merupakan salah satu dari sedikit suku yang masih kukuh-ketat menjaga tradisi kebudayaannya ditengah gelombang modernisasi di Indonesia. Mereka dikenal sebagai masyarakat yang sangat menjaga dan menghormati lingkungan alam tempat mereka hidup. Mereka beranggapan masuknya budaya modern akan melunturkan tradisi yang telah dibina, dijaga dan dikembangkan untuk kehidupan mereka, termasuk dalam hal menjaga kelestarian alam sehingga mereka kemudian menutup diri dan menolak segala bentuk ilmu dan teknologi moderen dari luar. Sementara orang menganggap bahwa mereka adalah masyarakat terbelakang, namun tentu saja pendapat tersebut keluar dari sudut pandang orang-orang yang melihatnya hanya dari sudut pandang modernisasi yang menjadi panutannya.

Perikehidupan masyarakat Badui dalam berinteraksi dengan alam niscaya dapat menjadi teladan bagi masyarakat modern dalam menghadapi tantangan pada saat ini. Pengetahuan apa yang dapat di gali dari tradisi bermukim dari masyarakat Badui, bagaimana pengetahuan ini dapat menjadi inspirasi dan dapat ditumbuh-kembangkan untuk menjawab tantangan pada saat ini. Benarkah bahwa tradisi bermukim masyarakat Badui merupakan ilmu tentang kehidupan berkelanjutan dari bangsa kita sendiri yang bahkan tidak kalah indahnya dengan ilmu "green living" pada saat ini. Bahkan ilmu tersebut bukan sekedar teori, namun telah dilakukan dikoreksi dan disesuaikan dengan waktu dan kondisi setempat dari generasi ke generasi.

Tujuan bahasan ini adalah untuk memberikan gambaran kehidupan masyarakat Badui dalam tradisi bermukim, khususnya dalam bidang arsitektur dan mengambil teladan untuk menghadapi tantangan kehidupan saat ini. Tujuan dicapai dengan cara menggambarkan permukiman dan aktifitas masyarakat, ketentuan dan larangan yang berlaku dalam kehidupan masyarakat yang menjadi panutan aktifitas masyarakat, memaknainya dalam kaitannya dengan kondisi dan tantangan pada saat ini.

\section{KEBUDAYAAN, TRADISI DAN ARSITEKTUR}

Ketika manusia memulai kehidupannya, dia akan dihapakan pada tantangan alam tempat dia hidup, manusia dengan akal pikirannya kemudian mencoba menyesuaikan dan mengelola alam untuk menunjang kehidupanya. Dari sinilah kebudayaan muncul dan berkembang seiring dengan perkembangan masyarakat dan kehidupannya. (Poerwanto,1997:60). Kebudayaan dengan demikian akan sangat tergantung pada siapa dan di mana sebagaimana dikatakan Oliver (2006:xxi) bahwa tidak ada kebudayaan yang sama dari masyarakat di tempat yang berbeda. 
Kebudayaan berkembang sebagaimana manusianya, artinya kebudayaan akan terus berubah menyesuaikan dengan kondisi alam dan masyarakatnya dari waktu ke waktu. Perubahan ini juga bisa disebabkan karena percampuran dengan kebudayaan lain karena interaksi dan pergaulan antar masyarakat (Poerwanto, 1997:64). Dalam suatu kebudayaan yang relatif tetap, kebudayaan tersebut tetap saja berubah, masalahnya adalah bagaimana perubahan tersebut tidak sampai merubah karakter inti dari kebudayaan tersebut dan terjadi secara lambat berangsur-angsur dari masa ke masa (Rapoport,1994:6). Pada pokoknya selama masyarakat pemegang kebudayaan tersebut menganggap bahwa kebudayaannya masih bernilai dan bermanfaat untuk melangsungkan kehidupannya, maka kebudayaan tersebut masih akan tetap dipertahankan dan diajarkan pada anak keturunannya sebagai bekal kehidupannya. Dengan demikian kebudayaan tersebut akan menjadi tradisi yang tidak banyak mengalami perubahan. Pada kebudayaan, tradisi akan menjadi ciri kuat yang menandai keberadaan masyarakat tersebut, sekalipun beberapa orang menganggap tradisi menandakan kekolotan dan keterbelakangan.

Manusia menyesuaikan dengan lingkungan alam dimana ia tinggal. Bentuk penyesuaian tersebut terlihat pada bagaimana ia membangun "sarangnya". Sebagai mahluk yang dikaruniai akal pikiran tentulah sarang ini tidak sekedar jadi karena nalurinya, melainkan melalui penelaahan dan pemikiran yang mendalam, baik dari segi fungsi, konstruksi, bahkan juga estetika serta simbolisasinya. Aturan-aturan membangun disepakati dalam kelompok suku dimana manusia tersebut tinggal tentunya setelah terbukti bahwa aturan-aturan tersebut terbukti dapat menyelesaikan pernasalahan yang terjadi pada saat itu. Kesepakatan ini kemudian juga diturunkan pada generasi selanjutnya. Dan selama aturan tersebut tetap dianggap up to date serta dapat menyelesaikan masalah pada generasi berikutnya maka aturan tersebut akan tetap dipakai dengan menyesuaikan pada perkembangan tantangan serta permasalahan yang terjadi (Asquith \& Velingga, 2006:7). Dengan demikian arsitektur hunian yang aturan-aturannya didapatkan secara turun temurun tersebut akan selalu mempunyai kesamaan cirri yakni pengaruh sosial dan budaya masyarakat, serta keterkaitan yang dalam dengan lingkungan alam setempat. Bentuk, tata ruang dari hunian dengan sendirinya akan merupakan hasil bersama yang dipengaruhi oleh kebudayaan, teknologi, material yang tersedia, iklim dan konstruksi (Rapoport, 1969:47).

\section{ARSITEKTUR BERKELANJUTAN}

Arsitektur pada dasarnya ditujukan untuk meningkatkan kualitas hidup manusia. Sebagai bagian dari lingkungan alam maka seharusnya peningkatan kualitas tersebut tidak hanya menyangkut manusia itu sendiri, namun juga lingkungan dimana ia tinggal dan berkehidupan. Menurut James Steele, arsitektur berkelanjutan adalah arsitektur yang mampu memenuhi kebutuhan pada saat ini dengan tidak membahayakan generasi mendatang dalam memenuhi kebutuhannya, dimanapun dia berada. Kebutuhan yang sudah tentu akan berbeda dari satu tempat dengan tempat lain dan dari satu waktu ke waktu selanjutnya. Secara umum arsitektur berkelanjutan akan menerapkan konsep pembangunan berkelanjutan, yakni konsep untuk mempertahankan sumber daya alam dan bahkan sumber daya manusia untuk dapat bertahan lebih lama. Dengan demikian pembangunan berkelanjutan mempuyai tiga kata kunci, yakni: pembangunan, kebutuhan dan generasi mendatang. Pembangunan berkelanjutan sendiri mendasarkan pada tiga pilar yakni pembangunan sosial, pembangunan ekonomi dan pembangunan lingkungan. Dari interaksi ketiga pilar tersebut maka pembangunan berkelanjutan akan merujuk pada pembangunan yang ekologis, yang memperhatikan lingkungan secara keseluruhan. Dalam bidang arsitektur pengembangan konsep pembangunan berkelanjutan kemudian menghadirkan bermacam-macam 'aliran' seperti Arsitektur Ekologis, Arsitektur Ramah Lingkungan, Arsitektur Hemat Energi, Arsitektur Bioklimatik, termasuk juga Arsitektur Hijau (Green Architecture). Devinisi untuk arsitektur hijau sendiri adalah arsitektur yang mencoba sehemat mungkin mengkonsumsi sumber daya alam dan meminimalkan dampak negatif terhadap lingkungan sehingga akan terjadi keselarasan antara manusia dengan lingkungannya. Konsep arsitektur arsitektur hijau ini akan

Sebagai sebuah gerakan untuk mencegah kerusakan dunia yang berkelanjutan, maka pada banyak negara-negara di dunia kemudian menerapkan konsep-konsep arsitektur tersebut dalam bentuk aturan membangun. Pada saat ini peraturan-peraturan tersebut masih dalam bentuk 'labelling' yakni memberikan predikat atau penghargaan pada bangunan atau karya arsitektur. Green Buliding Counsil, sebuah lembaga yang mengevaluasi bangunan-bangunan yang sudah maupun dalam perencanaan memberikan label mulai dari perunggu yang terendah sampai ke emas yang tertinggi. Pada saatnya kelak aturan-aturan tersebut tentu akan diterapkan dalam bentuk persyaratan pada setiap bangunan. 
Salah satu parameter untuk mengukur ke"hijau"an bangunan dapat dilihat pada Greenship Rating Tool untuk Gedung Terbangun versi 10 yang meliputi: Apropriate Site Development, Energi Evisiensi \& Conservation, Water Conservation, Material Resources \& Cycle, Indoor Health \& Comfort dan Building Environment Management. Tolok ukur tersebut kemudian dijabarkan lebih rinci serta disematkan nilai pada tiap-tiap bagiannya.

\section{PERMUKIMAN MASYARAKAT BADUI}

Suku Badui tinggal di daerah pegunungan di wilayah Kabupaten Lebak Propinsi Banten. Suku Badui sendiri terbagi menjadi dua, yakni Badui Dalam dan Badui Luar. Suku Badui Dalam dapat dikatakan adalah inti dari masyarakat Badui, mereka masih mempertahankan adat tradisinya dengan teguh. Mereka menolak budaya modern termasuk hasil-hasil kebudayaannya, alat elektronik, kendaraan dilarang dipakai, bahkan pendidikan modern tidak diperbolehkan. Mereka tinggal di wilayah desa Kanekes yang meliputi desa Cibeo, Cikeusik dan Cikertawarna. Penampilan masyarakatnya ditandai dengan pakaian berwarna putih atau hitam dan ikat kepala putih. Perangai masyarakatnya halus, polos serta jujur. Sementara masyarakat Badui Luar tinggal di desa-desa disekitarnya, sekalipun masih bersaudara, masyarakat badui luar sudah mulai melepaskan diri dari adat dan mengikuti perkembangan. Desa-desa Badui Dalam letaknya terpencil. Untuk mencapainya harus berjalan kaki sejauh lebih kurang 12 kilometer dari desa Cibolegar dengan medan naik turun berbukit-bukit. Tidak ada sarana transportasi untuk menuju ke desa Badui Dalam. Konon mereka selalu menolak rencana pemerintah untuk membangun jalan untuk memecahkan keterasingan tersebut, demikian juga rencana pembuatan sekolah dan sarana prasarana lingkungan yang lain. Menurut mereka sekali akses tersebut terbentuk maka gelombang pengaruh dunia luar akan sangat hebat dan mereka akan sangat sulit mempertahankan kemurnian adapt istiadatnya.

Permukiman masyarakat Badui Dalam berbentuk klaster dengan barisan rumah-rumah yang berjajar rapat. Terletak pada transis melandai di dekat aliran sungai. Transis yang miring akan memudahkan aliran air ketika hujan sehingga hampir tidak terdapat genangan di dalam lingkungan permukimannya. Orientasi rumah selalu ke Utara selatan, berhadap-hadapan dengan tetangga dalam jarak cukup rapat. Terdapat pelataran cukup luas untuk tempat berkumpul warga dengan rumah kepala desa atau Puun di ujungnya serta banjar tempat pertemuan dan rumah lesung tempat menumbuk padi di ujung yang lain. Lumbung padi terletak di tepi permukiman atau agak terpisah, merupakan kumpulan lumbung yang masing-masing dimiliki satu keluarga. Selain rumah satu satu keluarga umumnya mempunyai huma di ladang yang letaknya bisa agak jauh dari permukiman. Setiap satu kepala keluarga disediakan satu ladang yang luasnya sebanding dengan tenaganya untuk mengolah tanpa dibantu orang lain. Ketika musim tanam atau panen satu keluarga bisa tinggal di huma sampai berhari-hari.

Sungai menjadi prasarana lingkungan yang fital. Penggunaan sungai dibagi tiga. Bagian hulu digunakan untuk mandi, bagian tengah untuk mencuci dan bagian hilir untuk buang air. Air untuk minum diambil dari mata air atau pada bagian hulu sungai. Dilarang menggunakan sabun ketika mandi dan mencuci, dilarang menggunakan pasta gigi ketika sikat gigi. Larangan ini dimaksudkan untuk mencegah polusi pada aliran sungai.

Rumah tradisional Badui disebut Imah. Berbentuk empat persegi panjang dengan atap kampung dan sosoran di salah satu sisinya disebut atap sulah nyanda. Bagian dalam terdiri dari tiga ruangan, yakni sosoro, disisi selatan yang digunakan untuk menerima tamu; Tepas di sisi samping memanjang ke belakang dan digunakan untuk ruang kegiatan keluarga; Imah yang merupakan inti rumah, tempat tungku dan dapur serta digunakan untuk kegiatan intern keluarga. Ruang sosoro didepan menyambung dengan ruang tepas tanpa pembatas, membentuk huruf "L", smentara Imah tertutup dengan hanya satu pintu. Pintu rumah merupakan satu-satunya pintu masuk ke dalam rumah. Terdapat di sebelah sisi bangunan, ditandai dengan adanya emperan atau teras kecil serta anak tangga.

Konstruksi bangunan merupakan rumah panggung dengan material menggunakan bahanbahan bangunan yang terdapat di sekitar lokasi. Pondasi bangunan menggunakan batu utuh tanpa dipecah dan tidak tertanam. Batu ini digunakan untuk landasan tiang kayu rumah. Kostruksi utama rumah seperti tiang dan balok menggunakan kayu tanpa finishing. Sambungan-sambungan dengan purus dan coak diperkuat dengan pasak, tanpa paku. Rangka lantai menggunakan bambu, bagian atasnya ditutup dengan bambu pecah yang diratakan. Untuk tidur ataupun kegiatan yang lain biasanya kemudian dibentangkan tikar pandan. Dinding dibuat dari anyaman bambu dengan tulangan dari bambu motif anyaman seperti kepang. Anyaman pada dinding atas lebih jarangjarang sementara pada dinding bagian bawah lebih rapat. Anyaman model yang lain ditemui pada pintu masuk, berupa anyaman bambu fertikal dari bilah bambu. Anyaman dengan jenis yang 
mirip juga digunakan untuk alas tempat penyimpanan di atas dengan rangka dari bambu.

Rangka atap bangunan menggunakan kayu dengan rangka penutup atap dari bambu, sementara penutup atapnya menggunakan anyaman daun nipah. Secara umum konstruksi rumah menggunakan sistim knock down. Masyarakat Badui dalam membangun rumahnya biasa mempersiapkan elemen dan material bangunannya lebih dahulu, kemudian secara bergotong royong merakitnya menjadi sebuah rumah, sehingga waktu untuk mendirikan rumah tidak terlalu lama.

Lumbung tempat menyimpan padi dan hasil ladang juga merupakan bangunan yang cukup penting. Berupa rumah panggung beratap pelana dengan ukuran kecil. Pintu terdapat didinding bagian atas sehingga untuk memeasuki lumbung diperlukan tangga. Pada kaki-kaki rumah panggung terdapat dataran bundar seperi meja yang berfungsi untuk mencegah tikus maupun hewan lain naik ke lumbung. Dinding dari anyaman bambu yang dilapisi ijuk untuk merapatkan dinding dan menjaga suhu udara di dalam lumbung.

Rupanya pemanfaatan sumber daya alam setempat dilakukan maksimal secara kualitatif dan optimal secara kuantitatif. Bambu misalnya, merupakan bahan bangunan yang tersedia melimpah. Pemanfaatan bambu sangat dominan dalam pembangunan rumah, baik untuk elemen konstruksi maupun untuk elemen pembentuk ruang. Untuk masing-masing elemen tersebut masyarakat badui mengembangkan teknologi setempat yang walaupun sederhana tetapi sangat cocok dan optimal untuk kondisi setempat. Untuk jenis anyaman bambu setidaknya ada empat macam anyaman. Anyaman dinding atas yang renggang akan memudahkan sirkulasi udara bagian atas sementara anyaman dinding bawah lebih rapat agar aliran udara lebih terkendali. Anyaman pintu yang sering dibuka tutup dibuat lebih kokoh. Lantai dari bambu yang dipecah dan diratakan membuat jalinan antar pecahan bambu masih terjalin kuat dan rapat. Bambu juga dimanfaatkan untuk membuat perabot perabot rumah seperti tempat minum, tempat mengambil air bersih, tempat minyak sayur untuk penerangan serta tempat sampah. Semua perabot dibuat dengan bentuk tertentu untuk memudahkan kerja dan menghasilkan manfaat yang maksimal.

Pembangunan rumah dilakukan setelah mendapat persetujuan dari sesepuh setempat yang mendapat mandat untuk mengurusi masalah tersebut. Biasanya keluarga yang akan membangun rumah menabung materialnya lebih dahulu. Mengumpulkan kayu dan bambu untuk rangka rumah, anyaman bambu untuk dinding dan lantai, setelah cukup lengkap baru kemudian secara bergotong royong rumah didirikan dengan melibatkan seluruh warga masyarakat. Sementara para laki-laki bekerja membangun rumah, wanita memasak dan menyiapkan bagian-bagian yang lebih kecil. Kami pernah membangun 12 rumah hanya dalam waktu dua hari, kata pak

Masyarakat Badui secara adat bermata pencaharian sebagai petani, pertanian dilakukan dengan system ladang dengan mengandalkan hujan. Selain berladang mereka juga memanen hasil hutan seperti kopi, buah-buahan. Mereka lebih banyak memanfaatkan hasil pertanian atau hasil hutan untuk keperluan sendiri atau ditukarkan dengan bahan-bahan kebutuhan mereka. Jual beli dalam artian ekonomi tidak dilakukan masyarakat. Mereka tidak pernah berpikir untuk menimbun kekayaan atau melakukan investasi. "Kalau ada lebih ya disimpan untuk dimakan selanjutnya, kalau tidak punya ya ditukar dengan yang ada". Dalam bertani, setiap keluarga mendapatkan jatah tempat garapan di seputar desa, luasnya dibatasi sesuai dengan kekuatan dari keluarga tersebut membuka ladang dan mengelolanya sampai menghasilkan, tidak terpikir untuk memperkerjakan orang lain sehingga bisa membuka ladang seluasluasnya.

Ketika musim tanam tiba satu keluarga termasuk anak-anak akan pindah dari rumah menempati huma di dekat ladangnya. Sehari penuh satu keluarga ini akan bahu-membahu mengerjakan ladangnya. Mereka bisa tinggal selama berhari-hari sampai pekerjaan bertanam selesai dan dapat ditinggal. Karena hanya mengandalkan hujan, dalam satu tahun hanya dapat panen satu atau dua kali, diantara masamasa itu masyarakat menanam ubi atau jagung.

Diantara kesibukan dalam masa bertanam, masyarakat badui membuat kerajinan tangan untuk kemudian ditukarkan dengan bahan pangan yang diperlukan. Adakalanya mereka pergi ke luar daerahnya untuk melihat suasana luar. Semua perjalanan dilakukan dengan berjalan kaki, sekalipun harus menempuh waktu berhari-hari. Untuk ke Jakarta saja misalnya mereka harus menempuhnya dalam waktu dua hari. Keinginan melihat dunia luar sempat dilontarkan oleh Asep. Dimana letak kota Semarang kalau dari Jakara, apakah jalannya banyak cabangnya, bisa sampai tidak kalau menyusuri rel kereta api.

\section{HASIL DAN PEMBAHASAN \\ Green Architecture Pada Permukiman Masyarakat Badui \\ Pemilihan tapak menjadi hal yang krusial} ketika seseorang membangun tempat tinggalnya. Permukiman masyarakat Badui Dalam terletak 
pada wilayah yang melereng landai. Pada kemiringan yang landai ini masalah drainage dengan mudah diatasi dan lahan permukiman dapat senantiasa kering. Permukiman juga dibangun dekat dengan sungai dengan pertimbangan untuk kebutuhan keseharian. Pembagian penggunaan sungai menurut jenis kegiatan serta larangan untuk membuang serta menggunakan bahan-bahan asing ke sungai dilakukan untuk memastikan sungai tetap tidak tercemari oleh adanya kegiatan masyarakat permukiman tersebut. Tidak banyak penyesuaian tanah untuk kebutuhan permukiman tersebut, hanya batu-batu yang diletakkan sebagai tumpuan kolom-kolom kayu rumah. Pemilihan lokasi dan perlakuan terhadap lahan ini niscaya dapat memenuhi persyaratan Green Building pada bagian Apropriate Site Develoment serta Water Conservation.

Rumah tradisional masyarakat Badui hanya mengenal tiga ruangan dengan satu ruangan yang betul-betul terpisah dari ruang yang lain. Tentunya ruang-ruang tersebut dapat digunakan untuk bermacam-macam kegiatan yang sejenis. Ruang multi fungsi ini juga menjadikan ruangan menjadi efisien. Apalagi tidak banyak perabot yang digunakan untuk mendukung kegiatan dalam ruangan kecuali gelaran tikar untuk duduk bersila. Walaupun tidak sama persis dalam ukurannya, namun semua bangunan rumah relafif kecil dan semuanya terpakai secara optimal.

Kecuali struktur utama rumah, hampir semua material bangunan, bahkan sampai ke perabot dan peralatan rumah tangga mengeksplorasi bambu. Material yang sampai saat ini tersedia melimpah di wilayah tersebut. Bambu sendiri merupakan jenis material yang cukup kuat daya tahannya kalau diperlakukan dengan benar. Bambu tersedia cukup melimpah karena cepat pertumbuhannya serta mudah pemeliharaannya. Masyarakat Badui mempunyai perhitungan serta aturan yang dianut secara tradisionil ketika memanfaatkan bambu, baik untuk rumah maupun untuk keperluan yang lainnya. Tradisi ini akan dapat menjawab Material Resources \& Cycle.

Konstruksi rumah tradisional Badui menggunakan atap sulah nyanda. Atap pelana dengan kemiringan atap yang cukup tinggi untuk menjamin air hujan mengalir dengan cepat meninggalkan bentang atap. Penggunaan ilalang sebagai penutup atap selain ringan juga banyak tersedia serta mudah pemasangannya. Struktur bangunan berupa panggung dengan lantai cukup tinggi dari tanah. Dinding menggunakan anyaman bambu dengan bermacam fariasi anyaman. Bagi penghuni ruang, pemakaian material dan konstruksinya menjamin ruangan tetap teraliri udara dari celah-celah anyaman dinding bambu dengan intensitas serta kecepatan yang terjaga sehingga ruangan tetap sejuk dan kering. Letak lantai yang tinggi dari muka tanah menghindarkan lembab dari tanah mengalir ke ruangan. Lantai yang tinggi ini juga menghindarkan masuknya binatang serta serangga ke dalam rumah, meskipun tidak sepenuhnya berhasil dilakukan. Kenyamanan dan kesehatan ruang dalam kaitannya dengan pencahayaan mungkin perlu dipertanyakan karena bukaan dinding sangat sedikit di rumah tradisional Badui. Namun kalau melihat kehidupan keseharian masyarakat yang sebagian besar dilakukan di ruang luar, maka dapat dimengerti kalau pencahayaan dalam ruang tidak mendapatkan porsi perhatian yang besar. Meskipun harus dilihat pada konteks kehidupan masyarakat Bkiranya tradisi tersebut cukup menjawab parameter Indoor Health \& Comfort

Selain rumah utama, setiap keluarga masyarakat Badui juga mempunyai sebuah huma selain sebidang tanah untuk bertani sesuai kebutuhan keluarganya. Huma diletakkan di persawahan tempat dia bekerja. Setiap musim tanam satu keluarga akan pindah ke huma untuk mendekati tempatnya bekerja. Hal ini akan memperpendek jarak antara rumah dengan tempat kerjanya sehingga akan menghemat energi. Masalah hemat energi ini juga sangat ditunjang dengan kebiasaan masyarakat untuk bepergian kemanapun dengan hanya berjalan kaki. Masalah pencemaran yang disebabkan oleh sarana transportasi tidak dikenal di kalangan masyarakat Badui. Kehidupan malam masyarakat Badui lebih banyak dilalui dengan tidur. Untuk menghangatkan ruang, pediangan dapur dibiarkan tetap membara, namun dijaga untuk tidak menyala terlalu besar. Hampir tidak ada ruangan yang masih terang selain pediangan tersebut. Penerangan kalaupun diperlukan menggunakan minyak kelapa yang ditampung di tempurung dan diberi sumbu. Intuk menghasilkan pencahayaan yang lebih terang dan terarah, misalnya untuk menerangi jalan ketika bepergian malam hari digunakan tempurung kelapa yang dicat bagian dalamnya. Ini berfungsi seperti rumah lampu yang memantulkan dan mengarahkan cahaya dari nyala api minyak kelapa. Tradisi dan teknologi lokal tersebut kiranya dapat menjawab parameter tentang Energi Evisiensi \& Conservation.

\section{KESIMPULAN}

Mungkin ada yang berpendapat bahwa adalah sangat wajar masyarakat Badui sangat dekat dengan alam karena populasinya masih sedikit dibandingkan dengan daerah kediamannya, serta belum memerlukan tuntutan kebutuhan hidup sebagaimana masyarakat modern. Namun hendaknya kita berfikir bahwa 
justru ketika semua krisis belum terjadi, alangkah baiknya apabila kita mempunyai kearifan (wisdom) yang dapat kita gali dari masyarakat dan kebudayaan kita sendiri untuk menjaga segala anugerah tersebut sebagaimana dilakukan masyarakat Badui.

\section{DAFTAR PUSTAKA}

Asquith \& Felinga. 2006. Vernacular Architecture in The Twentinth Century. Taylor \& Francis, London \& New York.

GBCl 2011. Greenship Rating Tool untuk Gedung Terbangun versi 10. GBC Indonesia.

Hadi, Sudharto P. 2009. Manusia dan Lingkungan. BP Undip. Semarang.

Oliver, Paul. 2006. Built to Meet Needs, Cultural Issues in Vernacular Architecture. Elsevier, Oxford.

Pangarsa, Galih W. 2007. Merah Putih Arsitektur Nusantara. Penerbit Andi, Yogyakarta.

Poerwanto, Hari. 1997. Manusia, Kebudayaan dan Lingkungan. Depdikbud, Jakarta.

Rapoport, Amos. 1969. House Form and Culture. Prentice Hall, London.

Saraswati, T. 2011. Tantangan Menuju Arsitektur yang Lebih Tanggap Kondisi Bumi dan Lingkungan. Pidato Pengukuhan Jabatan Guru Besar pada Fakultas Arsitektur dan Desain Universitas Kristen Duta Wacana, Yogyakarta 12 Maret.

Wines, J. 2008. Green Architecture. Taschen Gmbh, Koln, Germany. 
Agung Budi Sardjono, dkk / Jurnal Teknik Sipil \& Perencanaan 19 (1) (2017) 57 - 64 